\title{
The Poetry and Anti-Poetry of Czeslaw Milosz Peter Filkins
}

\author{
I should relate sometime how I changed \\ My views on poetry, and how it came to be \\ That I consider myself today one of the many \\ Merchants and artisans of Old Japan, \\ Who arranged verses about cherry blossoms, \\ Chrysanthemums and the full moon.
}

$$
\text { -Milosz, "No More" }
$$

RESPONDING TO A REVIEW of his Collected Poems ${ }^{1}$ written by A. Alvarez for The New York Review of Books, Czeslaw Milosz recently wrote to that journal to protest Alvarez's use of "Witness" as a title for the piece. In the letter, despite what Milosz sees as a "longing" on the part of Western writers for "subjects provided by spasms of historical violent change," he contends that "we, i.e., natives of hazy Eastern regions, perceive History as a curse and prefer to restore to literature its autonomy, dignity, and independence from social pressure." Furthermore, because of his distrust of History and his belief that poetry should rise above it, $\mathrm{Mi}$ losz is quick to scold Alvarez for failing to "distinguish between our duty to preserve memory and our natural desire to move forward with our affairs of the living." For what bothers Milosz the most is that Alvarez never considers the poems as just that - poems, the central point of the letter being Milosz's confession of his own "uneasiness when I saw the long evolution of my poetic craft encapsulated by Mr. Alvarez in the word 'witness,' which for him is perhaps a praise [sic] but for me is not."2

Surprisingly, these are the words of a poet who titled his own Charles Eliot Norton Lectures at Harvard as The Witness of Poetry; one who, perhaps more than any other living poet, stands as a testament to the power of poetry to encompass human suffering on a large historical scale without ignoring the difficulty, if not impossibility, of the poet bearing such burdens to still advocate poetry's inherent capacity and urge for praise. In fact, despite his refusal to accept the role, Milosz is a witness, and one of the very best our own dim century has to offer us. Where his reluctance is 
justified, however, is in the manner with which critics often limit such a role to the experience witnessed rather than concentrating on the "autonomy" and "dignity" invested into how it is conveyed. In short, Milosz the man may be praised for having witnessed, survived, and reported many of the atrocities inflicted on his native Poland and Europe as a whole, but it's a distinction which has little to do with the making of good poems. Milosz the poet, however, is quite another matter. For it is the way he has conveyed his experience, the leaps in invention, form, expression, and craft that he has used to get at it, which, if nothing else, has made him a witness to poetry at its finest, as well as one of the most complex and imaginative writers this century has seen.

The most interesting aspect of Milosz's career is the variety of styles and subject matter emerging from it. A member of the Polish literary avantgarde known as the Catastrophists, Milosz began in the Thirties as one of the many writers who foresaw nothing but doom and destruction awaiting the modern world, much of his writing being devoted to the description of the catastrophe in order to protest against it. Seemingly prophetic, what the work had to say was confirmed, unfortunately, by the cataclysm of the Second World War and its aftermath swallowing whole Milosz's native Lithuania into the Soviet bloc, as well as the countless victims beneath the silence of History's deadly wake. When at last allowed to publish again, Milosz turned away from such abstract proclamations of death and destruction characterizing his early work and instead wrote a number of poems that dealt directly with the atrocities he had witnessed at the hands of the Nazis and the conquering troops. Poems such as "A Poor Christian Looks at the Ghetto" and "Child of Europe" are good examples of the concerns that haunted him in the Forties, their guilt-ridden awareness establishing Milosz as a voice of witness and protest, but one who accepted the role with deep reluctance because of the knowledge that, no matter how many times he might raise a cry of despair and rage, there were innumerable others who would never have the chance to do the same.

It was precisely this realization of poetry's inability to entirely capture or alter what had occurred which led to a crucial turn in Milosz's aesthetic during the Fifties. Having purged his nightmarish guilt and rage over historical events in prose discussions such as The Captive Mind and Native Realm, Milosz not only found it difficult to maintain a place in his poetry 
for such concerns, but also that there could be no place for them if he was to remain dedicated to the making of good poems and faithful to his own philosophical and aesthetic sense of integrity. Though he would continue to write for the next thirty years with one eye on History and the experience of suffering he had witnessed, Milosz chose increasingly to write specifically about the inability of any writing to lay hold of any reality while at the same time acknowledging that the pursuit of the Real is the only reason for picking up a pen in the first place. Yet what has always saved his work from an exhausted nihilism is the pure beauty of so many of his failed attempts at conveying experience, for given a poet of such talent, one who has so ably expanded poetry's reach to include philosophy, religion, and even prose, the measure of conscience he has brought to all of his work is a large part of what the poetry is all about. Though in his eyes a poem may be unable to match all that consciousness absorbs, Milosz sees the statement of this as an act of conscience he can neither ignore nor refute. Thus, what we end up with is a sort of "poetic anti-poetry," a deep and abiding conviction that, though those "artisans of Old Japan" may only be fooling themselves into believing that "verses about cherry blossoms" can capture the reality of cherry blossoms, it does not release the poet from the responsibility to still make the attempt at coalescing experience, perception, and memory into a human construct of not only what happens in this life, but also what does not.

Given the drastic change in Milosz's outlook over the years, it makes sense to look at his beginnings, especially now that The Collected Poems is available in such a handsome edition from Ecco Press, beautifully translated by Milosz himself at work with Robert Hass and several others. Covering some fifty-six years of writing with selections from thirteen volumes, the Collected begins quite rightfully with one of Milosz's earliest Catastrophist poems written in 1931. Titled "Artificer," it presents an anonymous figure walking through a nightmarish surround of "machines throbbing quicker than the heart, lopped-off heads, silk / canvases," the horror of which causes the figure to shake his fist at the sky in protest until he himself decides to take action in the final stanzas:

He wonders at his brother's skull shaped like an egg, every day he shoves back his black hair from his brow, then one day he plants a big load of dynamite 
and is surprised that afterward everything spouts up in the explosion.

Agape, he observes the clouds and what is hanging in them:

globes, penal codes, dead cats floating on their backs, locomotives.

They turn in the skeins of white clouds like trash in a puddle.

While below on the earth a banner, the color of a romantic rose, flutters

and a long row of military trains crawls on the weed-covered tracks.

Milosz writes in the Preface to The Collected Poems that it was Hass who insisted that this poem be included because of the "wild, anarchistic energy" "he found in it. Not only does this seem to show some reluctance on the part of Milosz to resurrect the poem, the comment by Hass serves as an incisive gloss on many of Milosz's early poems and the aims of the Catastrophists as a whole. Rebellious, surreal, yet at the same time prophetic, the voice and intent behind the poem seem so very foreign to the careful introspection that characterizes Milosz's best known work. Rather than a poem of witness reflecting back on experience and the frustrations of detailing it, we have here a warning siren whose trajectory is sounded towards a future that cannot help but come, the prophet of doom taking to the streets to both alert and denounce the citizens, and the warning in some ways sounding like a wish, such as here in "The Gates of the Arsenal" from 1934:

Flame, o flame, immense musics

Resound, movement stirs the groves,

With their hands tied, on gun-carriages, horseback,

Under immobile wind or blowing silent flutes,

Travelers pass each other, going round and round,

Showing each other their lips locked like frost,

Contorted in a scream, or their eyebrows

Ripped apart by wisdom, or fingers tearing open

Their breasts shorn of ribbons, medals, braids. 
While reading this, however, one must remember that much of its prophetic merit is based on the confirmation of such a vision by the grim reality of the decade that followed. What this means is that, despite whatever perverted pleasure we may take in seeing the prophet turn out to be right, it's the victim's blood that proves him so.

This is part of the guilt that Milosz had to face within himself after the war. Having watched his own worst fears confirmed in the destruction and dissolution of countries in the aftermath, he seems to have found no choice but to confront the realities at hand rather than attempt prophesizing new, harsher forms for the future. Yet before he was able to come face to face with the evil he had witnessed and survived, Milosz performed the first of the many imaginative leaps which characterize his poetic journey when he turned an about-face on the present and future by returning to the innocence of his past and childhood. In "The World," an eerie sequential poem written in formal verse and imbued with a childlike voice musing upon the shape and meaning of the immediacy of home and family, Milosz sets up the security of the child's understanding of a comprehensible world full of meaning and weight as a silent counterpoint to the shattered existence the adult poet must have experienced while writing about "Hope" in 1943:

Hope is with you when you believe The earth is not a dream but living flesh, That sight, touch, and hearing do not lie, That all things you have ever seen here Are like a garden looked at from a gate.

You cannot enter. But you're sure it's there. Could we but look more clearly and wisely We might discover somewhere in the garden A strange new flower and an unnamed star.

Some people say we should not trust our eyes, That there is nothing, just a seeming,

These are the ones who have no hope.

They think that the moment we turn away, The world, behind our backs, ceases to exist, As if snatched up by the hands of thieves. 
In a note to the poem, Milosz comments that the "deliberately naive tone can hardly find an equivalent in English," a statement which lays to rest any suspicion that the innocent tone is simply a side effect of the translation rather than a chosen conceit. Rather, the shock of any poet having chosen to write something so naively secure at such a dark moment in history is really what the poem is about, for what's most important about "The World" is the poet behind it who still maintains that such a perception is possible, even if only in memory. The childlike simplicity, the "neatly rhymed stanzas" which, according to the note, are "written in the style of school primers"; all of it amounts to not so much a refusal to accept the reality before him, but rather an inability to deny the sense of reality previously known, and the desperate need for it to return once more. For surrounding the naive consistency of a realm of understandable spirits is the onslaught of History which will arrive to destroy it, cannons and catastrophe silently poised on the edge of the child's understanding of "The Sun":

All colors come from the sun. And it does not have Any particular color, for it contains them all. And the whole Earth is like a poem While the sun above represents the artist.

Whoever wants to paint the variegated world Let him never look straight up at the sun Or he will lose the memory of things he has seen. Only burning tears will stay in his eyes.

Let him kneel down, lower his face to the grass, And look at light reflected by the ground.

There he will find everything we have lost:

The stars and the roses, the dusks and the dawns.

The realist in Milosz, however, could not ignore what had happened, nor for that matter his own inability to take it all in and make it comprehensible. In poems such as "A Poor Christian Looks at the Ghetto," it's as if the child of "The World" were suddenly transported to the present chaos, the simple catalogue of the objects of human suffering presented as 
the closest the poet can come to an embodiment of the victims who once possessed them:

Bees build around red liver,

Ants build around black bone.

It has begun: the tearing, the trampling of silks,

It has begun: the breaking of glass, wood, copper, nickel, silver, foam

Of gypsum, iron sheets, violin strings, trumpets, leaves, balls, crystals.

Poof! Phosphorescent fire from yellow walls

Engulfs animal and human hair.

A few years later in "Child of Europe," Milosz again returns to the idea of the child as a summation of an era's best hopes and possibilities. This time around, however, he does so quite sardonically, the child that once mused upon the simple beauties of "Hope" and "The Sun" now made guilty and conspiratorial because of having survived.

We, whose lungs fill with the sweetness of day,

Who in May admire trees flowering,

Are better than those who perished.

We, who taste of exotic dishes,

And enjoy fully the delights of love,

Are better than those who were buried.

We, from the fiery furnaces, from behind barbed wires

On which the winds of endless autumns howled,

We, who remember battles where the wounded air roared in paroxysms of pain,

We, saved by our own cunning and knowledge.

Yet in many ways this is still the voice of the Catastrophist raging against the world at large, unable to accept the complexity of human action in the face of good and evil. Accusatory, self-righteous, hell-bent on admonishing society of its comfortable follies and illusions; the fury erupting in 
poems like "Child of Europe" carries with it appreciably the same degree of malice that is behind the violence and negation which it so heatedly condemns. This is not to say that it's a failed poem because of this, for obviously the rage out of which it rises is a noble one. But before we jump on the bandwagon of its steely music, it might be wise to note that such a poem offers little to replace the doomed vision it provides. Unlike "The World," a poem that dares to display the fragility of hope and innocence against the backdrop of a world devoid of either, "Child of Europe" suffers from the dilemma of almost having to affirm the very world it battles against. Hence, the real danger here is that, in struggling with the tyrant, it's all too easy to become him.

Milosz himself takes up this problem in a good number of poems from the very same period, one of the most vital being "In Warsaw" from 1945. Here, instead of railing against what is witnessed, the poet begins to question his own reasons for formulating a stance against it, as well as wondering about the best one to choose:

What are you doing here, poet, on the ruins

Of St. John's Cathedral this sunny

Day in spring?

What are you thinking here, where the wind

Blowing from Vistula scatters

The red dust of the rubble?

You swore never to be

A ritual mourner.

You swore never to touch

The deep wounds of your nation

So you would not make them holy

With the accursed holiness that pursues

Descendants for many centuries.

Milosz, however, finds himself trapped. Though conscience may demand that he face what is going on around him and give it reality in his poems, consciousness remains limited in its ability to grasp all that has been lost. Yet the one juncture where the two can be united is in the paradox of the 
poet's need to accept the world and pay homage to it even when condemning the forces that have severed its moorings. By the end of the poem, Milosz transforms poetry's innate capacity for praise into moral action, for only through praise can an imagined world be asserted, an act which, as he states, is desperately needed in order that humanity survive amid the rubble and revolutions:

How can I live in this country

Where the foot knocks against

The unburied bones of kin?

I hear voices, see smiles, I cannot

Write anything; five hands

Seize my pen and order me to write

The story of their lives and deaths.

Was I born to become

a ritual mourner?

I want to sing of festivities,

The greenwood into which Shakespeare

Often took me. Leave

The poets a moment of happiness,

Otherwise your world will perish.

This kind of commitment to the world as it should be, versus the unfortunate guise of the world as it is, has remained a concern of Milosz's work ever since. At times positing poetry as a means of transcending the harsh realities of History and its victims, at others recognizing the futility of grasping the slightest trace of reality in song, the one thing Milosz has never become is "a ritual mourner." For him, the sanctity of the dead is the silence that they keep; a silence which, though it may haunt the living, can never be spoken for or used as cheap fodder for the making of poems. As "Dedication" makes clear, poetry may indeed be a necessity in life which should be practiced with all the seriousness of a moral and political act, but never can it hope to remake or revive the past and the lives lost to it. Rather, it can only act as a kind of shaman in attempting to ward off the dead so that the present can go on living: 
What is poetry which does not save

Nations or people?

A connivance with official lies,

A song of drunkards whose throat will be cut in a moment,

Readings for sophomore girls.

That I wanted good poetry without knowing it,

That I discovered, late, its salutary aim,

In this and only this I find salvation.

They used to pour millet on graves or poppy seeds

To feed the dead who would come disguised as birds.

I put this book here for you, who once lived

So that you should visit us no more.

What all of this boils down to is a battle between Good and Evil with poetry as the tactical grounds on which the fight is fought. On one side of the field stands Good: the human urge to express and give shape to the world as it is and to accept it for the imaginative possibilities it offers. Throughout Milosz's work, the context most often devoted to the Good is the litany of simple objects that fills so many of his poems, spoken with a cadence of worship and praise reminiscent of Whitman and encompassing the pure essence of textures and forms. Balanced against this is Evil: the bare-boned necessity of life and death, and the failure of spirit which refuses to distinguish between the two, such that all too often reality is warped and perverted by forces wishing to control everyday existence through power and idolatry rather than the search for understanding and essence. Where Good and Evil get confused, however, is when Milosz recognizes that poetry is also a means of controlling existence, or at least a limited version of it. Hence, if the poet is complacent enough to settle for whatever form of reality ends up in a poem without acknowledging the mystery and multiplicity of existence, then Evil is incurred by the acceptance of such a limitation placed upon reality. Furthermore, whenever the description of violent historical Evil enters the poem as part of the nature of what is, who is to say that this doesn't cater to a continuance of Evil by immortalizing it through the imaginative act? Clearly such a paradox not only demands that the poet choose wisely when selecting the material about which he will write, it also threatens the very ideals involved in the act of writing itself. 
This is the aesthetic and moral dilemma Milosz found himself in during the late Fifties and early Sixties. What's interesting is that he chose not to investigate it by discussing the immediate experience of his past life in Poland or his eventual exile from it. Instead, the springboard for the debate that continues is an ongoing argument about the nature of poetry, what it can accomplish and what it cannot, as in "No More," from which I took the epigraph for this essay because it sums up the major turn Milosz's career took and from which he has never wavered:

\section{I should relate sometime how I changed}

My views on poetry, and how it came to be

That I consider myself today one of the many

Merchants and artisans of Old Japan,

Who arranged verses about cherry blossoms,

Chrysanthemums and the full moon.

If only I could describe the courtesans of Venice

As in a loggia they teased a peacock with a twig,

And out of brocade, the pearls of their belt,

Set free heavy breasts and the reddish weal

Where the buttoned dress marked the belly,

As vividly as seen by the skipper of galleons

Who landed that morning with a cargo of gold;

And if I could find for their miserable bones

In a graveyard whose gates are licked by greasy water

A word more enduring than their last-used comb

That in the rot under tombstones, alone, awaits the light,

Then I wouldn't doubt. Out of reluctant matter

What can be gathered? Nothing, beauty at best.

And so, cherry blossoms must suffice for us

And chrysanthemums and the full moon.

"If only I could describe ... If only I could describe. ..." Such is the mantle of despair which seems to hang over Milosz's entire oeuvre. Given what he has seen, the poet's consciousness cannot help but try to replicate all that he has experienced in order that it contain some meaning. At the same 
time, given what he has seen, the poet's conscience tells him that it is impossible to reproduce the ineffable qualities of life and Being, and even worse, it would border on pride to think that he could. For though Milosz may only be concerned here with describing "the courtesans of Venice," the failure to reproduce their sensuous reality as seen by "the skipper of galleons" on the very day he came ashore, and more importantly, as seen by that very man, is tantamount to an utter failure on the part of poetry to bear witness to any reality, much less that of the shattered lives and civilizations Milosz has experienced firsthand. What's more, because of our grounding in humanity, it is impossible for the poet to stand outside of it, language being a tool the uses of which may indeed serve the eternal, but the problem is that the hand which wields it consists of timebound flesh. What results is a kind of philosophical dead end that allows for only the briefest glimpse of transcendence in any given moment, a process which Milosz expounds on somewhat disdainfully in "A Frivolous Conversation":

- My past is a stupid butterfly's overseas voyage.

My future is a garden where a cook cuts the throat of a rooster.

What do I have, with all my pain and rebellion?

- Take a moment, just one, and when its fine shell,

Two joined palms, slowly open

What do you see?

-A pearl, a second.

- Inside a second, a pearl, in that star saved from time, What do you see when the wind of mutability ceases?

- The earth, the sky, and the sea, richly cargoed ships, Spring mornings full of dew and faraway princedoms.

At marvels displayed in tranquil glory

I look and do not desire for I am content.

Yet conscience never quite lets go of its demands upon Milosz, and one of the key things to remember about him is that nothing is ever simple in 
his work and thought. Continually doubling back and forth between the opposing forces of wonder and futility, in many ways Milosz is a skeptic's skeptic, his own gritty integrity maintaining his ability to question without ever falling into slack meaninglessness. "This is the place; accepted, not chosen," he tells us in "It Was Winter," and it's this kind of clearheaded determination to take on adversity without coveting the struggle itself which keeps him honest and forever wary of pat answers. Though he might be inclined to refute the possibility of recreating the world lost to him, Milosz finds memory is the mesmerizing force that won't allow him to completely let go of the lives and events he has witnessed, no matter the difficulty of trying to recapture them. Writing about a woman lost to the past, Milosz admits in "Throughout Our Lands" that "Paulina died long ago, but is. / And, I am somehow convinced, not just in my consciousness." Similarly, it is always a "but" or a "somehow" which acts as the catalyst to his investigations, the cat's cradle of his thinking so often arriving at a complete conundrum only to extricate itself by changing the perspective or framework of the original question. In the same poem musing about the fate of Paulina, Milosz can state, "Only this is worthy of praise. Only this: the day," and yet in the very next stanza warn that "beneath it elemental powers are turning somersaults; / and devils, mocking the naive who believe in them, / play catch with hunks of bloody meat. ..." Though the two thoughts don't directly contradict one another, the gulf between their tone and perspective is what makes for the wrenched sensibility behind the poem, Milosz's range of thought leaping from one pole to another like a short circuit between parallel wires - volatile, unpredictable, and fully charged.

Exile, of course, is a proficient breeder of dualities, and one would be hard pressed to ignore the importance of exile in Milosz's writing. Having sought political asylum in France in 1951, Milosz would go on to take a position as Professor of Slavic Languages at Berkeley, but even more important than the escape to the West was his own inability to escape what he left behind. For a poet already well versed in dichotomies, the severing of time via space as a result of exile represents the epitomy of Milosz's struggle to retrieve the past through memory. Throughout the Sixties, his writing increasingly makes use of his new found American locale, but most often only as a comparison or sounding board for the return to Lithuania and the past. In "City Without a Name," a poem about his na- 
tive city of Wilno, Milosz writes movingly in one section about the difficulties of exile, the short triple rhyme stanzas reflecting the earlier childlike simplicity of "The World," but this time with all sense of wonder having been drained out long ago:

When I got rid of grieving

And the glory I was seeking,

Which I had no business doing,

I was carried by dragons

Over countries, bays, and mountains,

By fate, or by what happens.

Oh yes, I wanted to be me.

I toasted mirrors weepily

And learned my own stupidity.

From nails, mucous membrane,

Lungs, liver bowels, and spleen

Whose house is made? Mine.

So what else is new?

I am not my own friend.

Time cuts me in two.

Monuments covered with snow,

Accept my gift. I wandered;

And where, I don't know.

Hopelessness and loss, however, are always the grounds on which Milosz constructs his own breed of affirmation and inquiry in his work. Having begun the poem by asking, "Who will honor the city without a name ... ?" (meaning Wilno), and then considering his own destitute absurdity while driving through Death Valley and watching "an Indian . . . walking a bicycle uphill," Milosz perseveres against distance and time despite "The shortness of life, / the years quicker and quicker, / not remembering whether it happened in this or that autumn." Eventually, as 
if out of exasperation, he can only wonder at the fact that he wonders at all, himself perplexed and asking:

Why should that city, defenseless and pure as the wedding necklace of a forgotten tribe, keep offering itself to me?

What evil in me, what pity has made me deserve this offering?

It stands before me, ready, not even the smoke from one chimney is lacking, not one echo, when I step across the rivers that separate us.

Perhaps Anna and Dora Druzyno have called to me, three hundred miles inside Arizona, because except for me no one else knows that they ever lived.

What had earlier seemed like a lament for his own loss of place and direction is here transformed into a sense of awe, for despite being "three hundred miles inside Arizona," he still inhabits the past, or better yet, the past still inhabits him, through memory. In the battle waged constantly between conscience and consciousness, memory is the one means of returning to a moment to relive it, a safe haven of awareness, immediacy, and timelessness as he sees the vision of the two women rise up in his consciousness studying the desert that surrounds him:

They trot before me on Embankment Street, two gently born parakeets from Samogitia, and at night they unravel their spinster tresses of gray hair.

Here there is no earlier and no later; the seasons of the year and the day are simultaneous.

"Here" being the construct of memory, Milosz thus inhabits a realm outside of the necessities of time and place. Ironically, exile is what has delivered him the means by which to make this discovery, one that releases him to such an extent that even language cannot measure the vision gained as a result of his becoming a resident of past and present at once, where "In the 
immobile light I move my lips and perhaps I am even glad not to find the desired word."

"City Without a Name" also marks an interesting aspect of Milosz's development because it is the first of his poems which begins as poetry and ends as prose. Though the incorporation of prose into poetry is probably Milosz's most significant contribution to style in contemporary poetry, it is also something wholly aligned with the paradoxes in his life and thinking. In "To Raja Rao," for instance, he describes himself as "Ill at ease in the tyranny, ill at ease in the republic, / in the one I longed for freedom, in the other for the end of corruption." If we were to simply substitute "poetry" and "prose" for "tyranny" and "republic," the resulting syllogism is as representative of the schism in the poet's aesthetic as the one in his life. In fact, whenever Milosz arrives at a settled stance on poetry, he most often does it in prose. Not only does this add tension to his pursuits through the use of a compelling style, it also creates an "anti-poetry" which refuses to be rhythmically lulled into complacency while at the same time allowing the poet the freedom to include so much more in the entire poem.

"From the Rising of the Sun" and "The Separate Notebooks" are the two masterful examples of what Milosz's stylistic alchemy has afforded him in terms of breadth and reach in the last twenty years of his work. Both written in the Seventies, the first is a more extended attempt at retrieving the reality of his childhood in Wilno, even though in large part it's about his inability to do so. It begins:

Whatever I hold in my hand, a stylus, reed, quill or a ballpoint,

Wherever I may be, on the tiles of an atrium, in a cloister cell, in a hall before the portrait of a king,

I attend to matters I have been charged with in the provinces.

And I begin, though nobody can explain why and wherefore.

From this Milosz moves on to some sixty pages of poetry and prose while trying to delineate the precise fluctuations and constructs of his reality as filtered through memory and consciousness. An impossible task, one might suggest, but that is precisely the point, for as he quickly discovers, language itself is limited in its means to be all inclusive. Meditating on the 
name of a flower seen on the banks of the Rogue River in Oregon, the poet realizes the deceptive imprisonment of his own vocation when he states:

I sat by its loud and foamy current

Tossing in pebbles and thinking that the name

Of that flower in the Indian language will never be known,

No more than the native name of their river.

A word should be contained in every single thing

But it is not. So what then of my vocation?

Beyond the return to Wilno and its history, this is the central concern of the poem. As if trying to refute his own doubts, Milosz uses every means available to him to get at what he is after, whole sections being devoted to an encyclopedic discussion of the history of a Lithuanian town called "Lauda." To an uninformed Western eye, many of the passages can seem tedious, if not incomprehensible, but the impetus for them is a burning need on the part of Milosz to name his origins and draw the outline of the horizon which gave birth to his ancestry. Hence, through decidedly "antipoetic" prose, the poet creates an invisible poetic urge simply by violating rhythmic concerns in order to come closer to what's real. Just why he feels compelled to do so is spoken about in another section where he admits:

I lived a long life there, several times a hundred years.

On my conscience the fate of serfs and servants.

Who except me has pondered the life of Jasiulis

and his wife, and their son Gregory, and their four daughters,

And Matulis, Pranialis, Ambrozej, and their sisters Polonija,

Rajna, Dosjuda, and Bujkis? And Mik Zemojtiewicz

And his wife Kasiula, and Lawryn and Miloszajtis?

Who sifts in his hand their ashes, changed now into words?

None of these names is explained in the many footnotes to the poem, but there is no need for us to know. All that matters to the purposes of the poem is that Milosz himself knows and remembers. What is really at stake through all the long catalogues, the encyclopedic details, the names, the conjurings, is the drama of a mind battling to lay hold of elusive, watery 
time, all the while knowing that he cannot stay its passing but only describe it as best he can, and by whatever means necessary, as it vanishes through his hands.

Though it makes use of the same mixture of poetry and prose, "The Separate Notebooks" seems to come to terms with the manic futility that pervades "From the Rising of the Sun." Constructed as a series of passages selected arbitrarily from a set of consecutive notebook entries, the poem does away with any expectation of consistency or final arrival right from the beginning. Nor does it attempt to reach back to a specific locale such as Wilno, concerning itself instead with a more universal discussion of meaning and reality in Milosz's own life when he presents himself at the start:

An old man, contemptuous, black-hearted,

Amazed that he was twenty such a short time ago, Speaks.

Though he would rather understand than speak.

He loved and desired, but it turned out badly.

He pursued and almost captured, but the world was faster than he was.

And now he sees the illusion. ...

But the heavy doors are already closing

Behind which he will stay for a very long time

In air that does not know winter or spring,

In a fluorescence without mornings and without sunsets. . .

And all around him the voices are intoning.

So many that he could listen for centuries,

Because he wanted, once, to understand his poor life.

But to understand a life one must include many others as well. This is why "The Separate Notebooks" is a poem full of voices, both imaginary and real. It is as if, in the search for his own meaning, Milosz can only relate the echoes he hears from moments now lost to him. Such moments, however, also stand outside of History, for in his attempt to capture some essence of his own reality, Milosz finds himself writing to Cezanne as a fellow artist and imploring: 
I want to know where it goes, that moment of enchantment, to what heaven above, to the bottom of what abyss, to what gardens growing beyond space and time.

I want to know where the house of an instant of seeing is, when it's liberated from the eye, in itself forever, the one you pursued day after day circling a tree with your easels.

There is no answer, of course, but that does not matter: Milosz's is a life which consists primarily of questions. Even he seems to see the truth in this, at one stage of the poem allowing a nameless woman to speak up and scold him for his futile pursuits devoid of a simple appreciation of life and its treasures:

You talked, but after your talking all the rest remains. After your talking - poets, philosophers, contrivers of romances -

Everything else, all the rest deduced inside the flesh

Which lives and knows, not just what is permitted.

I am a woman held fast now in great silence.

Not all creatures have your need for words.

Birds you killed, fish you tossed into your boat,

In what words will they find rest and in what Heaven?

You received gifts from me; they were accepted.

But you don't understand how to think about the dead.

The scent of winter apples, of hoarfrost, and of linen:

There are nothing but gifts on this poor, poor earth.

It's at moments like this that "The Separate Notebooks" conveys a richness of tone and subject matter beyond estimation, as well as beyond the very pain which the poet suffers in his failure to attain complete understanding. Milosz may continue to mourn his inability to attain a unified understanding of his life, but what cannot be ignored is the incredible amount of life he encompasses in such a poem. Fluctuating between memories of his childhood, musings about artists such as Cezanne and 
Proust, and disembodied voices from the bleak landscape of the past, the collage effect Milosz employs not only offers us a stunning display of his talents, it also depends upon our awareness of the one life capable of holding together such disparate versions of reality, namely the poet himself. As if having gone so far in this process that he can actually stand outside of his own being and observe it from a distance, later on Milosz turns to prose to observe in the third person:

He hears voices but he does not understand the screams, prayers, blasphemies, hymns which chose him for their medium. He would like to know who he was, but he does not know. He would like to be one, but he is a self-contradictory multitude which gives him some joy, but more shame.

What we take away from this, though, is the nobility involved in such wounded earnestness. When reading Milosz, one always gains the feeling of having lived a better, more focused life simply because of his own refusal to deny the complexity of existence, as well as its fragmentary joys. By the same token, he is also a poet who never seems to write just for the sake of writing, but rather for the need to investigate, to argue, to muse, to doubt, and to understand. The fact that poems as long as "The Separate Notebooks" and "From the Rising of the Sun" are difficult to summarize is testament to the complexity, irony, and invention woven into their making. For what each of them attempts to describe is a life - the fertile, flawed, voluptuous esse of a single human being - namely that in Milosz which, though it may fail in the attempt, must make use of the poem to get at what is beyond the poem while also making sure that every error incurred along the way is at least a human one.

In one of the many new poems translated and published in The Collected Poems for the first time, Milosz makes "A Confession":

My Lord, I loved strawberry jam

And the dark sweetness of a woman's body.

Also well-chilled vodka, herring in olive oil,

Scents, of cinnamon, of cloves.

So what kind of prophet am I? Why should the spirit

Have visited such a man? Many others 
Were justly called, and trustworthy.

Who would have trusted me? For they saw

How I empty glasses, throw myself on food,

And glance greedily at the waitress's neck.

Flawed and aware of it. Desiring greatness,

Able to recognize greatness wherever it is,

And yet not quite, only in part, clairvoyant,

I knew what was left for smaller men like me:

A feast of brief hopes, a rally of the proud,

A tournament of hunchbacks, literature.

That which on the part of most writers would seem a denial is, in Milosz, an affirmation. For this is the same writer who, in "Poet at Seventy," sums up in prose his deepest desire:

To find my home in one sentence, concise, as if hammered in metal. Not to enchant anybody. Not to earn a lasting name in posterity. An unnamed need for order, for rhythm, for form, which three words are opposed to chaos and nothingness.

In the juxtaposition of these two statements lies the essence of Milosz. On the one hand distrustful of his own motives and talents, on the other worshipping the aims of poetry at its finest, Milosz wishes only to observe the limits of poetry as a conveyance, and just that, of human desire. As a product of human invention, poetry must also bear the flaw of the hand that writes it, for though it may be able to leap beyond the bounds of time inflicted upon the poet, it also must remain a part of this life by evoking the consciousness and conscience of the poet himself. "Do you want white peacocks? - I will give you white peacocks," " says a voice out of nowhere in "The Hooks of a Corset." The ploy behind it, though, is Milosz's conviction that, no matter the appeal of the image or the poem, any effort at depicting reality is as illusory as the concept of Being itself, though the search for either is the one aim poetry can neither deny nor ignore.

"And yet the world is different from what it seems to be / and we are other than we see ourselves in our ravings." This, taken from "Ars Poetica?" depicts the degree of balance which the poetry of Czeslaw Milosz has to offer. A witness to History and a witness to poetry's urge to 
transcend it, Milosz has performed his greatest service to the art by reminding its practitioners of how serious an act it can be to write a poem. At the same time, anyone not interested in writing poetry has just as much to gain from reading Milosz, for even more important is his emphasis on the trials any one life must face in attempting to get at the essence of what it means to be alive and knowing. Memory, consciousness, conscience; these are the cornerstones of Milosz's art, the careful handling of them the foundation of his integrity as a witness to his time and the vestiges of humanity still managing to find a place to flourish within it. Unsurprisingly, it's that same questioning "Ars Poetica?" which stands at the center of his career, for in the end its last two stanzas, firmly entrenched in their own irony, serve as a touchstone to all Milosz has sought after, all he has accomplished, and everything he has tried to say in poem after beautiful poem down through years:

The purpose of poetry is to remind us how difficult it is to remain just one person, for our house is open, there are no keys in the doors, and invisible guests come in and out at will.

What I'm saying here is not, I agree, poetry, as poems should be written rarely and reluctantly, under unbearable duress and only with the hope that good spirits, not evil ones, choose us for their instrument.

Notes

1. Czeslaw Milosz. The Collected Poems. Ecco 1988. 511 pp. $\$ 30.00$ (cloth).

2. The New York Review of Books. Vol. xxxv, No. 12 (July 21, 1988) 42. 